\title{
A revision of the complex species Persoonia mollis (Proteaceae)
}

\author{
Siegfried L. Krauss and L.A.S. Johnson
}

\begin{abstract}
Krauss, Siegfried L. ${ }^{1}$ E Johnson, L.A.S. ${ }^{2}\left({ }^{1}\right.$ Department of Biology, University of Wollongong, NSW, Australia 2500; ${ }^{2}$ National Herbarium of New South Wales, Royal Botanic Gardens, Sydney, NSW, Australia 2000) 1991. A revision of the complex species Persoonia mollis (Proteaceae). Telopea 4(2): 185199. Persoonia mollis $\mathrm{R}$. Br. sens. lat. is circumscribed and revised, and a key and descriptions are provided for the nine taxa recognised as subspecies. Five new subspecies are described in P. mollis: subsp. maxima S. Krauss \& L. Johnson, subsp. nectens S. Krauss \& L. Johnson, subsp. leptophylla S. Krauss \& L. Johnson, subsp. livens S. Krauss \& L. Johnson, and subsp. budawangensis S. Krauss $\&$ L. Johnson. Three new combinations are made: P. mollis R. Br. subsp. caleyi (R. Br.) S. Krauss \& L. Johnson, P. mollis R. Br. subsp. revoluta (Sieber ex Schultes \& Schultes f.) S. Krauss \& L. Johnson, and P. mollis R. Br. subsp. ledifolia (A. Cunn. ex Meisner) S. Krauss \& L. Johnson.
\end{abstract}

\section{Introduction}

Persoonia mollis sens. lat., as here defined, is clearly separated from all other species, and constitutes a monophyletic group. It embraces four species recognised by Bentham (1870: 398-399): P. caleyi R. Br., P. revoluta Sieber ex Schultes \& Schultes f., P. ledifolia A. Cunn. ex Meisner, as well as P. mollis R. Br. (sens. strict.). The recognition of these four species led to much confusion and uncertainty regarding their limits, as well as difficulty in the determination of quite typical specimens of each, and even of other quite distinct species. Increased herbarium material, as well as acquaintance with the plants in the field, has led to a better understanding. We have concluded that the three subspecies listed under informal designations in Jacobs and Pickard (1981) do not adequately reflect the extent of variation within the group. The overall morphological variation is complex and in places somewhat clinal in nature, but nine allopatric and parapatric taxa can be distinguished. Some of these are connected by more or less broad hybrid zones, while others apparently have sharp boundaries. This is discussed further under each of the taxa treated below.

Although the assemblage includes taxa of quite strikingly different aspect and suggests comparison with some others treated as species-groups (e.g. the P. nutans P. myrtilloides group) by Weston and Johnson (1991), we have considered it appropriate at this stage to recognise a single broadly defined species, treating the nine component taxa as subspecies.

$P$. mollis sens. lat. possesses a clear and significant synapomorphy that unites the subspecies and distinguishes the clade from all others. Persoonia fruits are fleshy drupes with a hard woody endocarp surrounding the (usually) single seed (Johnson \& Briggs 1975). The endocarp in Persoonia, anatomically and in transverse section, is typically a solid, continuous woody structure composed of stone cells with very small humina. The P. mollis endocarp, however, contains a number of large tanniniferous sclereids with large lumina interspersed throughout the normal structure of the endocarp. Further, the combination of linear to lanceolate convex leaves that have recurved to revolute margins and are markedly paler beneath, short erect pedicels, pubescent to villous perianth, yellow anthers that lack appendages, glabrous ovary, 2 ovules and small drupe distinguishes $P$. mollis sens. lat. from all other species. 
One of us (SK) is currently undertaking studies into the population biology of this complex. The emphasis is on ecological and genetic (allozyme) variation, in an attempt to elucidate evolutionary processes within the group. Some resolution of the taxonomy of this group is a necessary precursory step to these studies. Also, a revision of the complex is required now for forthcoming volumes of the Flora of New South Wales and the Flora of Australia.

All specimens cited below have been seen by us unless otherwise indicated.

Persoonia mollis R. Br.

Brown (1810a: 161; 1810b: 372)

TyPe Citation: 'In Novae Hollandiae ora orientali: prope Port Jackson: ad ripas arenosas fluviorum (ubi v.v.).'

Lectotype (here designated): New South Wales: Banks of the Grose, R. Brown 3285 (BM). Possible isolectotypes: Port Jackson, R. Brown, 1803 (NSW 21316, ex BM); Port Jackson, R. Brown, (NSW 21317, ex BM); Port Jackson, R. Brown, 1801-1805 (NSW 131413, ex BM); Port Jackson, R. Brown,- (NSW 21318, ex BM?, ex MEL?).

Linkia mollis (R. Br.) Kuntze (Kuntze 1891: 579).

For further synonyms see under the subspecies.

Prostrate and spreading to erect and branching shrub, $0.2-5 \mathrm{~m}$ high, usually as broad as high (broader in subsp. revoluta). Bark smooth, pale metallic-grey to brown. Hairs silky, short to long (0.2-3 mm long), appressed to patent, pale to copper-orange. Branchlets slightly angular, from silky-pubescent or spreading-pubescent to densely villous. Leaves alternate (spiral phyllotaxy), or some subopposite or sometimes opposite-decussate or whorled, spreading or suberect, not twisted, sessile or narrowed to a very short petiole, linear-filiform, linear, linear-oblong, oblong-lanceolate, narrowlanceolate, lanceolate, or oblong-ovate, acute, acuminate, obtuse or truncate, $1.5-12 \mathrm{~cm}$ long, $0.8-17 \mathrm{~mm}$ wide, always transversely convex with margins from closely revolute to slightly recurved, the upper surface markedly darker green than the lower surface, smooth or somewhat scaberulous above, the lower surface markedly more pubescent than the upper, always \pm hairy when young, glabrescent, pubescent or villous when mature; venation obscure to evident (brochidodromous), when evident usually only the midvein prominent. Inflorescence an auxotelic botryum, 1-30-flowered; rachis 0-15 $\mathrm{cm}$ long. Flowers solitary, each subtended by a leaf or rarely by a reduced or scale leaf, on short pubescent pedicels $1-3 \mathrm{~mm}$ long; buds just prior to anthesis 8-12 mm long, silky-pubescent, pubescent, villous, or densely villous, rarely \pm glabrous; tepals yellow, 7-11.5 mm long, obtuse or caudate, usually constricted below the anthers, abaxial surface shortly and sparsely pubescent to densely villous; anthers $(2.5-) 3-4.5(-5) \mathrm{mm}$ long, yellow; filaments $2.8-4.8 \mathrm{~mm}$ long; glands deltoid or truncate, short, not very prominent. Ovary glabrous, stipitate, the stipe $0.6-1.5 \mathrm{~mm}$ long; ovules 2. Drupe stipitate, obliquely ovoid-globular or subglobular, small, c. $8 \mathrm{~mm}$ long, c. $7 \mathrm{~mm}$ diam., green becoming purplish-brown, crowned by the slender persistent style; endocarp woody, interspersed with tanniniferous sclereids. Cotyledons (4-) $5(-6)$.

FLOWERING PERIOD: Late December to May and occasionally as late as August (see also under the subspecies).

HaBiTAT: Widespread, from exposed coastal heath, to dry and wet sclerophyll forest and woodland, to very sheltered and moist gullies, predominantly on sandy soils on sandstone and undifferentiated metasediments, from near sea-level to $1100 \mathrm{~m}$ altitude (see also' under the subspecies). 
Distribution: Central and South Coast regions of New South Wales from O'Hares Creek catchment area to Durras Lake, and Central and Southern Tableland regions from the upper and lower Blue Mountains south to the southern Budawang Range, and west to Goulburn, with a disjunct occurrence in the Hornsby area (Figure 1).

\section{Key to the subspecies}

1 Leaves large, lanceolate to narrow-lanceolate, 4-8(-12) $\mathrm{cm}$ long, 6-17 $\mathrm{mm}$ broad, the margins recurved (often minutely)

2 Buds (and to a lesser extent young branchlets and young leaves) densely villous (velvety) to villous with erect, whitish to copper-coloured hairs 1-3 $\mathrm{mm}$ long. Leaves (young leaves especially) soft

3 Buds (and to a lesser extent young branchlets and young leaves) densely villous (velvety) to villous, the hairs c. $1 \mathrm{~mm}$ long, whitish when fresh, copper-coloured when dried

1. subsp. mollis

$3^{*}$ Buds (and to a lesser extent young branchlets and young leaves) villous, the hairs c. 2-3 mm long, copper-coloured when fresh or dried

2. subsp, maxima

$2^{*}$ Buds (and to a lesser extent young branchlets and young leaves) (sparsely-) silky-pubescent, the hairs c. $0.5 \mathrm{~mm}$ long, whitish. Leaves pliable but not very soft

3. subsp. nectens

$1^{*}$ Leaves small, linear to linear-lanceolate to oblong-lanceolate to oblong-ovate, $1.5-4(-6) \mathrm{cm}$ long, $0.8-6(-15) \mathrm{mm}$ broad (those leaves broader than $0.6 \mathrm{~cm}$ are shorter than $4 \mathrm{~cm}$ ), the margins revolute (rarely recurved)

4 Leaves linear-lanceolate to oblong-lanceolate to oblong-ovate, $2-6(-15) \mathrm{mm}$ broad, the apex acute, acuminate or obtuse, the margins recurved to revolute (the undersurface exposed when dried)

5 Habit prostrate, spreading, 0.1-0.5 m high, up to $4 \mathrm{~m}$ diameter. Large leaves usually broader than $6 \mathrm{~mm}$, obtuse (-acute) 5. subsp. revoluta

5* Erect shrubs $1.2-4 \mathrm{~m}$ high. Leaves always $<6 \mathrm{~mm}$ broad, acute to \pm obtuse

6 Leaves linear-lanceolate to narrow-lanceolate, $3-6 \mathrm{~cm}$ long, the apex acute

8. subsp. caleyi

$6^{*}$ Leaves oblong-lanceolate to oblong-ovate, 2-4 cm long, the apex \pm obtuse

7 Buds at anthesis 9-11.5 mm long. Longest hairs on buds and young leaf undersurface $0.4-1 \mathrm{~mm}$ long. Fitzroy Falls area, north of Kangaroo Valley

4. subsp. ledifolia

$7^{*}$ Buds at anthesis 7.5-10.5 mm long. Longest hairs on buds and young leaf undersurface $0.2-0.6 \mathrm{~mm}$ long. Endemic to the Budawang Range

9. subsp. budawangensis

$4^{*}$ Leaves linear to linear-filiform, $0.8-1.5(-2) \mathrm{mm}$ broad, the apex truncate to bluntly acute or obtuse, the margins tightly revolute (when dried the under surface wholly or largely obscured). Dense, compact shrubs $0.8-1.5(-2) \mathrm{m}$ high

9 Undersurface of leaves densely villous with closely appressed hairs Leaves green to grey-green 7. subsp. livens

9* Undersurface of leaves sparsely villous to villous with closely appressed hairs. Leaves bright green

6. subsp. leptophylla 


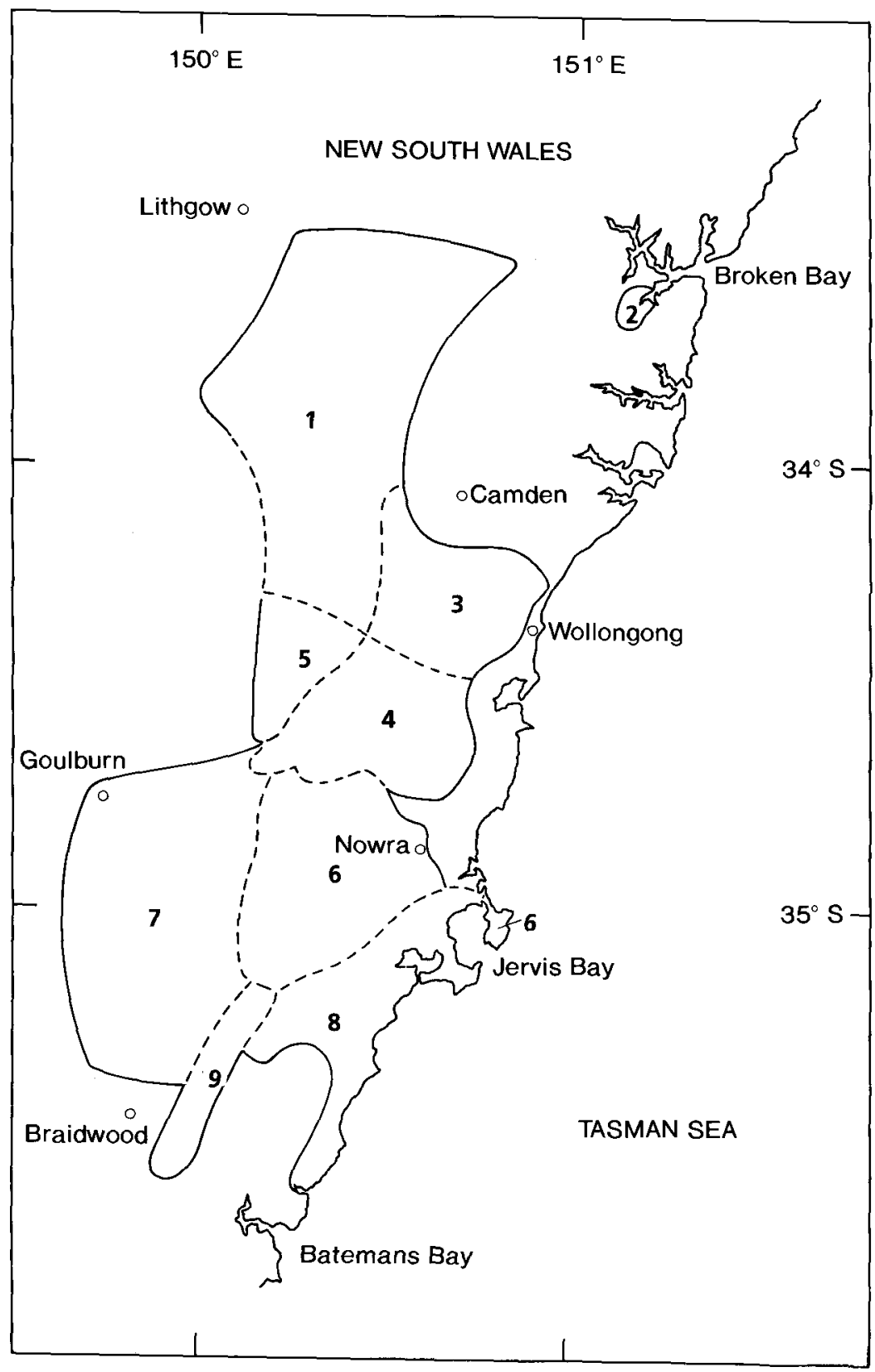

Figure 1. Distribution of Persoonia mollis subspecies: 1, subsp. mollis. 2, subsp. maxima. 3, subsp. nectens. 4, subsp. ledifolia. 5, subsp. revoluta. 6, subsp. leptophylla. 7, subsp. livens. 8, subsp. caleyi. 9, subsp. budawangensis. Solid lines indicate more or less exact boundaries. Broken lines indicate either approximate boundaries or hybrid zones. 


\section{Persoonia mollis $R$. Br. subsp. mollis}

Erect, branching shrub $1.5-5 \mathrm{~m}$ high. Young stems villous to velvety with erect, whitish to copper-coloured hairs. Leaves soft, narrow-lanceolate, acute, 4-10 cm long, 0.6$1.5 \mathrm{~cm}$ wide, villous to velvety on the undersurface when young, the longest hairs of moderate length, c. $1 \mathrm{~mm}$ long, erect, whitish to copper-coloured, the margins (minutely) recurved, the midvein usually prominent. Buds villous to densely villous with erect whitish to copper-coloured hairs c. $1 \mathrm{~mm}$ long. Figure 2.

FLOWERING PERIOD: Late December to April (and sporadically until June).

HABITAT: Dry to wet sclerophyll eucalypt forest with a shrubby understorey, in moist, sheltered, forested gullies, rarely in more exposed sites, on sandy soils derived predominantly from (Triassic) Hawkesbury Sandstone and Narrabeen Group sandstone.

Distribution: Widespread but sporadic throughout the upper and lower Blue Mountains (Figure 1).

CONSERVATION STATUS: not rare.

Notes: This subspecies is apparently parapatric with subsp. nectens in the Warragamba Dam catchment area. More collections are needed to determine the exact nature of the variation in this area, which could be somewhat clinal.

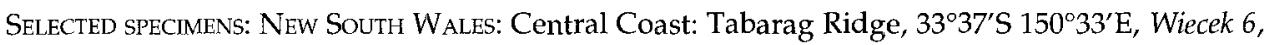
18 Mar 1987 (NSW); $5.3 \mathrm{~km} \mathrm{~W}$ of Kurrajong Heights, 333' ${ }^{\circ} \mathrm{S} 150^{\circ} 35^{\prime} \mathrm{E}$, Coveny 12102 \& Dunn, 15 May 1985 (NSW, B, K, PERTH); c. 1 mile [2.5 km] from Bilpin to Mountain Lagoon, Salasoo 3200, 25 Apr 1966 (NSW); Woodford, Cheel, Sep 1913 (NSW 21307); Frasers Gully, Springwood, Camfield, Mar 1899 (NSW 20924); The Valley, near Springwood, Maiden, 7-14 Apr 1888 (NSW); Erskine Creek, 10 miles [16 km] S of Glenbrook, Whaite 902, Apr 1951 (NSW). Central Tablelands: Wolgan East, Constable, 14 Dec 1948 (NSW 20934); Mt Wilson, Johnson, 22 Sep 1949 (NSW 14530); Mt Wilson, Fletcher, Jan 1894 (NSW 20926); Mt Victoria, Maiden, Dec 1896 (NSW 21299); Shipley Rd, Blackheath, Burgess, 27 Feb 1969 (NSW 124902 ex CBG 026091); Lawson, Dwyer, Mar 1924 (NSW 21306); Katoomba area, along Six Foot Track to Nellies Glen, $33^{\circ} 42^{\prime} \mathrm{S}$ $150^{\circ} 17^{\prime} \mathrm{E}$, Taylor 314 \& Coveny, 23 Oct 1984 (NSW, B, K, MO, NBG, PERTH, RSA); Tableland Rd, Kings Tableland, $4.8 \mathrm{~km}$ from Great Western Hwy, 33 $3^{\circ} 46^{\prime} \mathrm{S} 150^{\circ} 23^{\prime} \mathrm{E}$, Weston 1267 \& Catling, 31

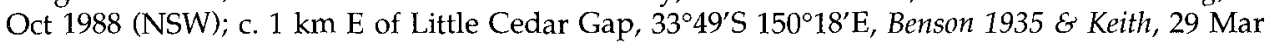
1984 (NSW); Jenolan Caves district, Blakely, Jan 1900 (NSW 20927). Precise locality uncertain: Blue Mountains, Cunningham 43, 1817 (NSW, ex BM); Blue Mountains, Cunningham 5, 1827 (NSW 113874, ex BM); New South Wales, Sieber 54, 1823 (NSW 131504, ex BM).

\section{Persoonia mollis $R$. Br. subsp. maxima S. Krauss $\mathcal{E}$ L. Johnson, subsp. nov.}

Frutex usque ad $5 \mathrm{~m}$ altus, villosus pilis cupreo-aureis $2-3 \mathrm{~mm}$ longis, foliis acutis $6-$ $12 \mathrm{~cm}$ longis $1-1.7 \mathrm{~cm}$ latis.

Holotype: New SOUth WAles: Central Coast: c. $700 \mathrm{~m} \mathrm{~S}$ of Ku-Ring-Gai Rd and c. 100 $\mathrm{m}$ E of Sydney-Newcastle Freeway, Ku-ring-gai Chase National Park, 334ㅇ's $151^{\circ} 09^{\prime} \mathrm{E}$, S. Krauss 206 \& L. Howitt, 24 Mar 1990 (NSW 228176).

IsOTYPES: AD, B, BRI, CBG, K, MEL, MO, PERTH.

Tall, branching, spreading shrub 2-5 $\mathrm{m}$ high. Young stems villous with erect coppercoloured hairs. Leaves soft, narrow-lanceolate to lanceolate, acute, 6-12 cm long, 1-1.7 $\mathrm{cm}$ wide, sparsely villous to villous on the undersurface when young, the hairs c. 2$3 \mathrm{~mm}$ long, erect, pale to copper-coloured, the midvein usually prominent, the margins (minutely) recurved. Buds sparsely villous to villous, the hairs erect, coppercoloured, c. $2.5-3 \mathrm{~mm}$ long. Figure 2.

DERIVATION OF EPTHET: From the Latin maximus, greatest or largest; referring to this 


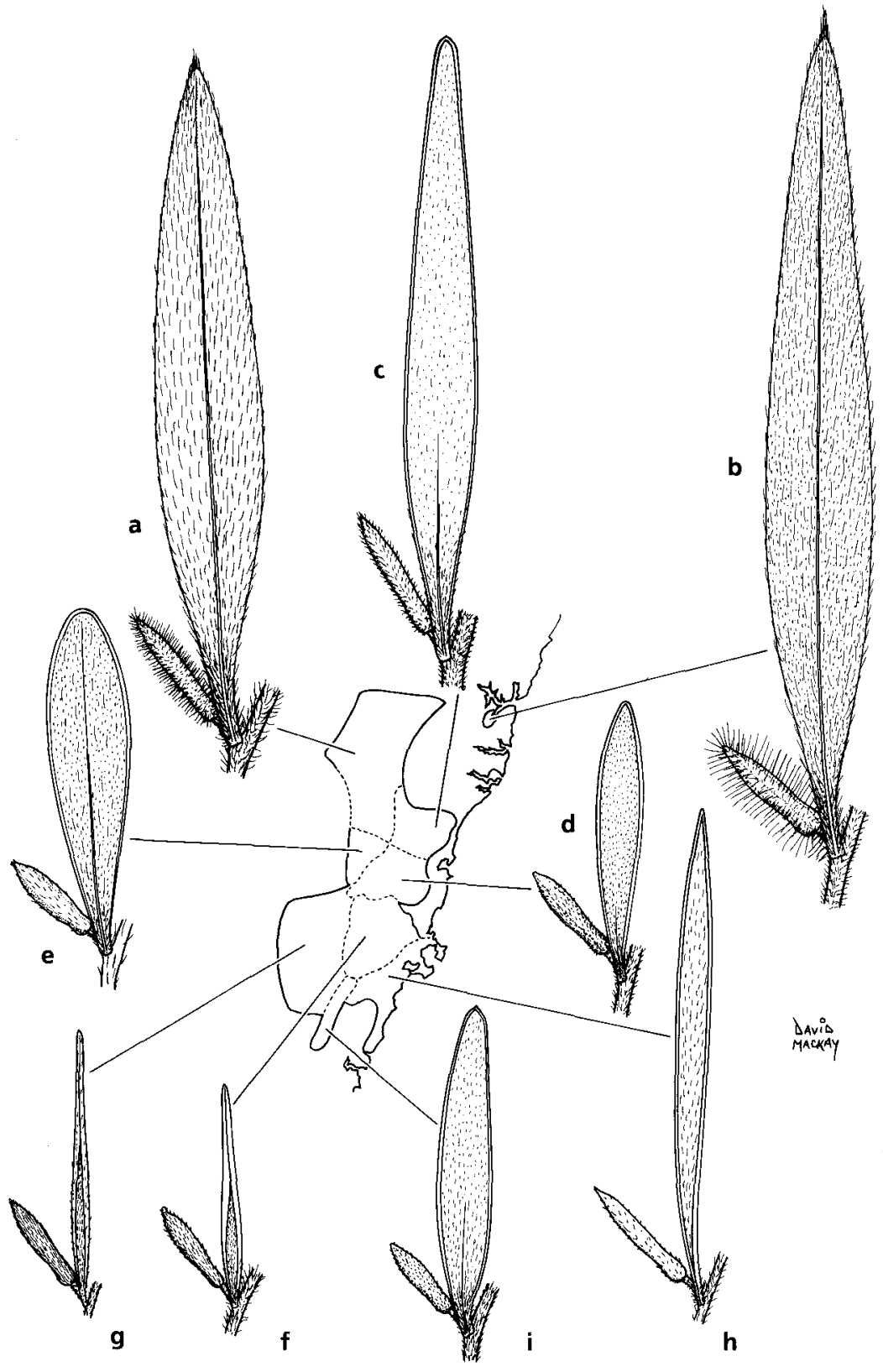

'Figure 2. Typical leaf (undersurface) and bud of each Persoonia mollis subspecies ( $\mathrm{x}$ 1.2): a, subsp. mollis ( $R$. Brown NSW 21317). b, subsp. maxima (holotype). c, subsp. nectens (holotype). d, subsp. ledifolia (Krauss 204). e, subsp. revoluta (Krauss 237 \& Johnson). f, subsp. leptophylla (holotype). g, subsp. livens (holotype). h, subsp. caleyi (Krauss $227 \&$ Howitt). i, subsp. budawangensis (holotype). 
subspecies being generally larger in its parts (habit, leaves, buds, flowers, hairs) than all other $P$. mollis subspecies.

FLOWERING PERIOD: Late December to April.

HАвітAт: In sheltered places in dry sclerophyll (Angophora costata - Eucalyptus pilularis) forest with a shrubby scleromorphic understorey, on shallow sandy soils derived from (Triassic) Hawkesbury Sandstone.

Distribution: Restricted to the Hornsby-Asquith-Cowan/Bobbin Creeks area (Figure 1). Only a handful of extant plants are known.

CONSERVATION Status: 2EC (using the coding system of Briggs \& Leigh (1988)).

NoTEs: These plants occur extremely sporadically, and only very small populations are known to us. This subspecies is geographically isolated from all others. It is morphologically and geographically closest to $P$. mollis subsp. mollis, which occurs about $50 \mathrm{~km}$ to the west.

Specimens eXamined: New South Wales: Central Coast: Hornsby, Blakely, Apr 1915 (NSW 21311); Cowan and Bobbin Creek, Blakely, Mar 1915 (NSW 21310); above gully SE of Asquith golf course,

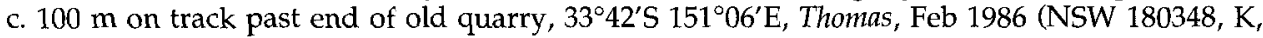
PERTH); Asquith, below the waterfall, Blakely, 24 Feb 1918 (NSW 20921).

\section{Persoonia mollis $R$. Br. subsp. nectens S. Krauss $\mathcal{E}$ L. Johnson, subsp. nov.}

Inter subspecies mollem et ledifoliam. Frutex 1-3 $\mathrm{m}$ altus, indumento pilorum pallidorum brevium (c. $0.5 \mathrm{~mm}$ longorum), foliis obtusis vel subacutis $4-10 \mathrm{~cm}$ longis $0.8-1.5$ cm latis.

Holotype: New SOUth Wales: Central Coast: 10R Fire Trail, c. $100 \mathrm{~m} \mathrm{~W}$ of O'Hares Creek, $34^{\circ} 13^{\prime} \mathrm{S} 150^{\circ} 53^{\prime} \mathrm{E}$, D. Keith 122, 1 Apr 1984 (NSW).

Medium to tall, erect, spreading, branching shrub 1.2-3 $\mathrm{m}$ high. Young stems sparsely villous with short, whitish, spreading hairs. Leaves mesophyllous, pliable but not soft, narrow-lanceolate, obtuse to subacute, $4-10 \mathrm{~cm}$ long, $0.8-1.5 \mathrm{~cm}$ wide, (sparsely) silky-pubescent on the undersurface when young, the hairs short, c. $0.5 \mathrm{~mm}$ long, pale, spreading, the midvein obscure to prominent, the margins (minutely) recurved. Buds (sparsely) silky-pubescent, the hairs c. 0.5-1 mm long, pale. Figure 2.

DERIVATION OF EPITHET: From the Latin nectens, binding or connecting, referring to the intervening position geographically and morphologically of this subspecies in relation to subsp. mollis and subsp. ledifolia.

FLoWERING PERIOD: Late December to April (and sporadically until June).

HABITAT: Dry to wet sclerophyll eucalypt forest, usually in moist sheltered sites, on sandy soils derived from (Triassic) Hawkesbury Sandstone.

Distribution: South-west of Sydney, from Oakdale south to Hill Top, and east to the Illawarra escarpment (Figure 1).

CONSERVATION STATUS: not rare.

Notes: North and south-west of Oakdale this subspecies may well intergrade with subsp. mollis, although more collections are needed from this area. Specimens from the Hill Top area differ slightly from typical subsp. nectens specimens in being slightly more pubescent. In this regard they approach subsp. mollis morphologically, and perhaps should be regarded as somewhat intermediate between subsp. mollis and subsp. nectens. For this treatment, however, we have included them in our con- 
cept of subsp. nectens. South-west of Mt Kembla, the exact boundary between subsp. nectens and subsp. ledifolia is unknown, and more collections are needed from the Lake Avon and Lake Nepean water catchment areas.

Selected SPECIMENS: New South Wales: Central Coast: Oakdale to Burragorang Lookout, Johnson, 5 Sep 1951 (NSW 20928); 2 km ESE of Oakdale Colliery, Weston 422, 27 Sep 1984 (NSW); Loddon Falls, Rodway, 11 Aug 1935 (NSW 38769); Cataract Catchment area, 34 ${ }^{\circ} 1-^{\prime} \mathrm{S}$ 150 4-'E, White 5095, 22 Oct 1927 (NSW, ex BRI); Cataract River, Cheel, 10 Mar 1907 (NSW 21322); Sublime Point, near Bulli Pass, C. Davis, Feb 1941 (NSW 38790); Mt Keira, Cheel, 3 Mar 1912 (NSW 21323); Illawarra district, Hamilton, Oct 1900 (NSW 21328); Wattle Ridge Rd, 4 km NW of Hill Top Post Office, $34^{\circ} 20^{\prime} \mathrm{S} 150^{\circ} 28^{\prime} \mathrm{E}$, Weston 433 \& Dalby, 15 Jan 1985 (NSW); Wattle Ridge $\mathrm{Rd}, 2 \mathrm{~km}$ N of Hill Top Post Office, 34²0'S 150²9'20"E, Weston 1040, Crisp \& Kater, 6 Nov 1986 (NSW).

4. Persoonia mollis $R$. Br. subsp. ledifolia (A. Cunn. ex Meisner) S. Krauss $\mathcal{E}$ L. Johnson, comb. et stat. nov.

Basionym: Persoonia ledifolia A. Cunn. ex Meisner (Meisner 1856: 339).

TYPe CitATION: 'Illawarra, A. Cunningham.'

Lectotype (here designated): New South Wales: Illawarra, A. Cunningham (NY). Possible parts of the type collection (not seen): The Mountains of the Five Islands District Southward of the Colony of New South Wales, A. Cunningham no. 17, $1824(\mathrm{~K})$; Little Mountain near Bullhi, Illawarra, A. Cunningham no. 17, 1824 (K).

Persoonia revoluta Sieber ex Schultes \& Schultes f. var. angustifolia Benth. (Bentham 1870: 398). Lectotype (here designated): New South Wales: Hanging Rock, Argyle County, McArthur (K, photo NSW). Excluded sYNTYPE: Blue Mountains, Atkinson (K, photo NSW).

Linkia ledifolia (A. Cunn. ex Meisner) Kuntze (Kuntze 1891: 579)

Small to medium, erect, branching shrub 1-2.5 m high. Young stems silky-pubescent with short, pale, spreading hairs. Leaves pliable but not soft, linear-oblong to oblonglanceolate, subacute to acuminate to obtuse, 2-4 cm long, $0.3-0.6 \mathrm{~mm}$ wide, (sparsely) silky-pubescent on the undersurface when young, the hairs c. $0.7 \mathrm{~mm}$ long, pale, spreading, the midvein obscure, the margins recurved to revolute. Buds (sparsely) silkypubescent, the hairs $0.4-1 \mathrm{~mm}$ long, pale. Figure 2.

FLOWERING PERIOD: Late December to April.

HaBITAT: Heath and dry sclerophyll eucalypt forest with a shrubby scleromorphic understorey, on shallow sandy soils derived from (Triassic) Hawkesbury Sandstone.

Distribution: From the Robertson area south to the Shoalhaven River and west to the Wingello-Penrose area. (Figure 1).

Conservation status: not rare.

Notes: In the Penrose-Wingello area, $P$. mollis subsp. ledifolia intergrades with subsp. livens. These plants have narrow-oblong to linear leaves, morphologically intermediate between the two subspecies. They seem to be confined to the same dry sclerophyll eucalypt forest on Hawkesbury Sandstone in which subsp. ledifolia is found. P. mollis subsp. livens, however, does not occur on (Triassic) Hawkesbury Sandstone. Rather it is found on older (upper Ordovician) undifferentiated sediments. This suggests that these intermediates have a closer affinity to subsp. ledifolia than to subsp. livens.

This subspecies possibly also intergrades with subsp. nectens (see under that subspecies). 
In the southern extent of its range it does not seem to come into contact with subsp. leptophylla, nor to the west with subsp. revoluta.

Selected SPeCimens: New South Wales: Central Coast: Illawarra, Shepherd, - (NSW 21327); top of ridge, Woodhill, 5 miles [9 km] from Berry, Rodway, 8 Jun 1930 (NSW 38783, K); road from Cambewarra Mtn to Berry Mt, Maiden, Sep 1905 (NSW 21326); top of Kangaroo Mtn, Cambage 1317, Sep 1905 (NSW). Central Tablelands: above Minnamurra Falls, Judd, 23 Apr 1954 (NSW 40160); East Kangaloon, c. $3 \mathrm{~km}$ NNW of Robertson, Coveny 931, 28 Feb 1969 (NSW); Robertson-Burrawang water supply reserve, at the locked gate, $34^{\circ} 33^{\prime} \mathrm{S} 150^{\circ} 35^{\prime} \mathrm{E}$, Weston 412,8 Jul 1984 (NSW); Barren Grounds Nature Reserve, at the carpark, $34^{\circ} 40^{\prime} \mathrm{S} 150^{\circ} 47^{\prime} \mathrm{E}$, Krauss 204 , 17 Feb 1990 (NSW, AD, B, BRI, CANB, CBG, HO, K, MEL, MO, NBG, PERTH, RSA); Jamberoo Mtn, on mountain road to Robertson, N.W. Rodd, 27 Jan 1950 (NSW 21325, CBG); Fitzroy Falls, Garden, Feb 1950 (NSW 21336); NE corner of E. Demuth's property (lot 167), Jamberoo Mountain Rd, Carrington Falls, 34 $37^{\circ} \mathrm{S} 150^{\circ} 40^{\prime} 40^{\prime \prime} \mathrm{E}$, Weston 1389 \& Bishop, 7 Apr 1989 (NSW 214242); Carrington Falls, Constable, 22 Jan 1955 (NSW 32230); Bundanoon, Constable, 7 Jan 1950 (NSW 11357).

P. mollis subsp. ledifolia - P. mollis subsp. livens intergrades:

Specimens eXamined: New South Wales: Central Tablelands: Sandy Creek, $15 \mathrm{~km}$ (direct) S of Moss Vale (on Meryla side), $34^{\circ} 40^{\prime} \mathrm{S} 150^{\circ} 23^{\prime} \mathrm{E}$, Johnson 8357, 16 Oct 1977 (NSW); Garbutt's area, Meryla State Forest, McGillivray, 26 Feb 1959 (NSW 85109); Penrose, Burgess, 8 Nov 1968 (NSW, ex CBG 025751); Penrose, Constable, 22 Jan 1956 (NSW 36569); Wingello State Forest, Constable, 21 Jan 1956 (NSW 36565); Goulburn-Bungonia, Moore 2738, 20 Oct 1953 (NSW); Goulburn district, Moore, Feb 1865 (NSW 21525).

5. Persoonia mollis $R$. Br. subsp. revoluta (Sieber ex Schultes $\mathcal{E}$ Schultes f.) S. Krauss $\mathcal{E}$ L. Johnson comb. et stat. nov.

BASIONYM: Persoonia revoluta Sieber ex Schultes \& Schultes f.

Schultes and Schultes (1827: 272).

Type Citation: Nova Hollandia, Sieber, Fl. Nov. Holl. no. 48, 1825.

Lectotype (here designated): New South WaLEs: Nova Hollandia no. 48, Sieber, 1825 (B). POSSIBLE ISOLECTOTYPE: Nova Hollandia no. 48, Sieber (K, not seen).

Linkia revoluta (Sieber ex Schultes \& Schultes f.) Kuntze (Kuntze 1891: 579).

Prostrate, spreading shrub, 10-50 cm high, up to $4 \mathrm{~m}$ diam.. Leaves glossy-green, pliable but not soft, almost fleshy, elliptical to oblong-ovate to oblong-lanceolate, obtuse (to rarely acute), 2.5-4 cm long, 4-10 (-15) mm wide, sparsely silky-pubescent to glabrous on the undersurface when young, the longest hairs c. $0.7 \mathrm{~mm}$ long, the midvein obscure or (rarely) prominent, the margins revolute. Buds sparsely silkypubescent to \pm glabrous, the hairs $0.3-1 \mathrm{~mm}$ long, pale. Figure 2 .

FLOWERING PERIOD: Late December to early March (and then sporadically until April).

НАвттAт: Dry sclerophyll eucalypt forest (E. sclerophylla) with a shrubby scleromorphic understorey on deep grey-white sand (apparently not usually on skeletal soils) over (Triassic) Hawkesbury Sandstone.

Distribution: Occurs sporadically in a restricted area west of Mittagong to Bullio, and south to Berrima and Canyonleigh (Figure 1).

CONSERVATION STATUS: 2Ri (according to the coding system given in Briggs \& Leigh (1988)).

Notes: Although apparently parapatric, this subspecies should perhaps be considered as allopatric. Although it borders three other $P$. mollis subspecies (subsp. nectens, subsp. 
ledifolia, and subsp. livens), neither actual contact nor intermediates between these three subspecies and subsp. revoluta have been found. The low, spreading habit and bright green foliage give subsp. revoluta a very distinctive appearance, though it shares the general characters of $P$. mollis as here treated.

Selected specimens: New South Wales: Central Tablelands: Mittagong, Dixon, - (NSW 21335); Mittagong, Baker, Jan 1903 (NSW); Soapy Flat Rd, 3.3 km NW of Wombeyan Caves Rd, 34 23'40"S 150²0'50"E, Weston $1418 \mathcal{E}$ Krauss, 18 Dec 1989 (NSW); Wombeyan Caves Rd, at junction of road to Kanangra property, $34^{\circ} 23^{\prime} \mathrm{S} 150^{\circ} 18^{\prime} \mathrm{E}$, Krauss $237 \mathcal{E}$ Johnson, 19 Apr 1990 (NSW); High Range, W of Mittagong, Cosh, late 1972? (NSW 127932); Bullio, Burgess, 25 Feb 1962 (NSW 56996); near Bungadilly, c. 11 miles [18 km] directly WNW of Berrima, McGillivray 1541, 11 Dec 1965 (NSW); 'Craigenbrae', c. $20 \mathrm{~km} \mathrm{~W}$ of Hume Hwy on Canyonleigh Rd, Richards 128, Armstrong \& Millar, 17 Feb 1990 (NSW).

\section{Persoonia mollis $R$. Br. subsp. leptophylla $S$. Krauss $\mathcal{E}$ L. Johnson, subsp. nov.}

Frutex compactus $0.5-1.5 \mathrm{~m}$ altus, indumento sericeo-pubescenti ad maturitatem sparso, foliis laetevirentibus rigidis lineari-filiformibus vel filiformibus $1.5-4 \mathrm{~cm}$ longis $0.08-0.2 \mathrm{~cm}$ latis marginibus valde revolutis.

Holotype: New South Wales: Southern Tablelands: $5.8 \mathrm{~km}$ E of Tianjara Falls on the Nowra to Nerriga road, $35^{\circ} 06^{\prime} \mathrm{S} 150^{\circ} 16^{\prime} \mathrm{E}$, S. Krauss 205, 17 Feb 1990 (NSW). ISOTYPES: AD, B, BRI, CANB, CBG, CHR, DNA, HO, K, MEL, MO, NBG, PERTH, RSA.

Persoonia linearis Andr. var. sericea Benth. (Bentham 1870: 397).

Holotype: New South Wales: Shoalhaven River, C. Moore, May 1867 (K, photo).

Small to medium-sized, erect, branching but compact shrub $0.5-1.5 \mathrm{~m}$ high. Young stems silky-pubescent. Leaves bright green, rigid, linear-filiform to linear, truncate to acute, $1.5-4 \mathrm{~cm}$ long, $0.08-0.2 \mathrm{~mm}$ broad, sparsely villous to villous on the undersurface when young and often also when mature, the hairs c. $0.7 \mathrm{~mm}$ long, pale, closely appressed to the leaf undersurface, the midvein obscure, the margins extremely revolute to the extent that on dried specimens the undersurface is wholly or partly obscured. Buds (sparsely) silky-pubescent, the hairs $0.3-1 \mathrm{~mm}$ long, weakly spreading. Figure 2.

Derivation of EPITHET: From the Greek leptos, slender, and phyllon, a leaf; referring to the very narrow leaves.

FLOWERING PERIOD: Late December to May (and then sporadically until July).

НАвітАт: Dry sclerophyll eucalypt forest with a dense scleromorphic shrubby understorey, open eucalypt woodland with a scrubby or heathy understorey, and tall and low (coastal) heath, on shallow sandy soils derived from (Permian) Nowra Sandstone and (Permian) Conjola Formation sandstone on Beecroft Peninsula.

Distribution: Southern Morton National Park area, south of the Shoalhaven River, east of Nerriga, north of the Budawangs, and west of Nowra, with a disjunct occurrence on Beecroft Peninsula (Figure 1).

CONSERVATION STATUS: not rare.

Notes: In the Jervis Bay area P. mollis subsp. leptophylla intergrades with subsp. caleyi. The variation in this area can also be interpreted as being part of a greater (but not uniform) cline extending from the higher altitudes in the Sassafras area to the coast at Jervis Bay and then south to Durras Lake. Morphologically, the leaves of subsp. leptophylla are shortest on those plants just west of Sassafras. They gradually become longer with lower altitude towards Jervis Bay, although through this part of the cline 
they remain as narrow as those at Sassafras (i.e. the undersurface of the leaf is not visible on dried specimens because of the revolute margins, although on living material they are not as inrolled). Extending south from Jervis Bay (subsp. caleyi), the trend is for leaves to be longer, and also broader, (i.e. with undersurface of leaves visible on dried specimens) so that at the southern extent of the range (Lake Durras) the leaves are almost lanceolate. In this regard, the boundary between these two subspecies appears somewhat arbitrary. The distinction drawn here correlates with a distinction in the substrate (subsp. leptophylla is almost restricted to Nowra Sandstone, subsp. caleyi is found only on Conjola Formation sediments). Other ecological factors such as habitat (vegetation) and rainfall possibly also correlate with the distribution of these two subspecies, although these need to be further investigated.

The locality of one specimen (Georges River, Deane, NSW 22020), is probably incorrect. This specimen is clearly subsp. leptophylla, and was probably collected in the vicinity of Nowra.

Selected spectmens: New South Wales: Central Coast: 1.7 miles [2.8 $\mathrm{km}] \mathrm{W}$ along Illaroo Rd, Nowra (N side of the river), 34 ${ }^{\circ} 52^{\prime} \mathrm{S} 150^{\circ} 35^{\prime} \mathrm{E}$, Coveny 3964 \& Bisby, 10 Mar 1972 (NSW); Nowra Nth., Constable, 8 Dec 1950 (NSW 16436); Burrier, Shoalhaven River, left bank, Rodway, Feb 1923 (NSW 38756). South Coast: Nowra, Rodway, 3 Mar 1934 (NSW 38755, K (Rodway 1268)); Falls Creek, Rodway, Feb 1923 (NSW 38740); c. $1.5 \mathrm{~km}$ from Currarong Rd along Lighthouse Rd to Pt

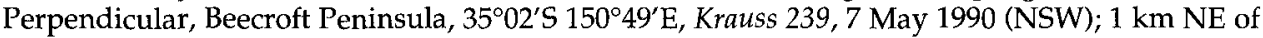
Honeymoon Bay on road to Lighthouse Rd, Beecroft Peninsula, $35^{\circ} 03^{\prime} \mathrm{S} 150^{\circ} 48^{\prime} \mathrm{E}$, Krauss 241,8 May 1990 (NSW); $1 \mathrm{~km}$ from Lighthouse Rd on road to Beecroft Hill, Beecroft Peninsula, $35^{\circ} 04^{\prime} \mathrm{S} 150^{\circ} 51^{\prime} \mathrm{E}$, Krauss 244,8 May 1990 (NSW); Nowra to Sassafras, c. 10 miles [17 km] SW of Nowra, Salasoo 3117, 9 Jan 1966 (NSW 90217); Tianjara Falls, c. 35 km SW of Nowra on Nowra-

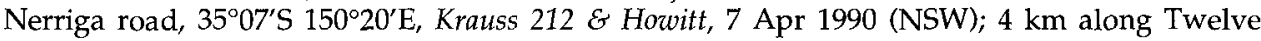
Mile Rd from the Nowra-Nerriga road, 35 $09^{\prime} \mathrm{S} 150^{\circ} 21^{\prime} \mathrm{E}$, Krauss 214 \& Howitt, 7 Apr 1990 (NSW). Southern Tablelands: Nerriga, between Nerriga and Towga above The Jumps, Walker 1145, Oct 1963 (NSW 69307, ex CANB); 2 miles SSW of Ettrema Trig., near Dogleg Ck, Ettrema Plateau, Johnson \& Briggs 3011, 15 Mar 1969 (NSW); near Ettrema Ck, Olsen 2435, 28 Jan 1975 (NSW); Mt Bulee, 7 miles [11 km] NE of Nerriga, Pigeon House Range, Constable, 28 Oct 1957 (NSW 46253); Nerriga, Nowra-Braidwood Rd, Boorman, Jan 1915 (NSW 20946); Nerriga-Braidwood Rd, E of Endrick River crossing, Blaxell 103, 8 Dec 1968 (NSW); Sassafras, 10 miles [17 km] NE of Nerriga, Constable, 9 Mar 1961 (NSW 53914); c. 17 miles E of Nerriga along Braidwood-Nowra Rd, $35^{\circ} 08^{\prime} \mathrm{S} 150^{\circ} 16^{\prime} \mathrm{E}$, Hartley 14272, 25 Mar 1975 (NSW, ex CANB).

\section{Persoonia mollis $R$. Br. subsp. livens S. Krauss \& L. Johnson, subsp. nov.}

Subspecie leptophylla similis sed foliis liventi-viridibus pagina inferiore dense villosa distinguitur.

Holotype: New South Wales: Southern Tablelands: Lower Boro, $28 \mathrm{~km} \mathrm{~N}$ of Braidwood, $35^{\circ} 10^{\prime} \mathrm{S} 149^{\circ} 16^{\prime} \mathrm{E}$, P. Kodela 4076, Jan 1989 (NSW).

ISOTYPE: CBG.

Small to medium-sized, erect, branching but compact, obconical shrubs $0.5-1.5 \mathrm{~m}$ high. Young stems silky-pubescent. Leaves grey-green, rigid, linear-filiform to linear, truncate to acute, $1.5-3 \mathrm{~cm}$ long, $0.08-0.2 \mathrm{~cm}$ broad, densely villous on the undersurface when young and often also when mature, the hairs pale, c. $0.5 \mathrm{~mm}$ long, closely appressed to the leaf undersurface, the midvein obscure, the margins extremely revolute to the extent that on dried specimens the undersurface is wholly or partly obscured. Buds silky-pubescent, the hairs c. $0.5 \mathrm{~mm}$ long, weakly spreading. Figure 2.

DERIVATION OF EPITHET: From the Latin livens, becoming leaden-green, from the greyergreen appearance of the foliage in contrast to the brighter green of subsp. leptophylla. The ' $i$ ' is pronounced long; in the English pronunciation this is as in 'alive'. 
FLOWERING PERIOD: Late December to March.

HABITAT: In dry sclerophyll eucalypt woodland with an open shrubby scleromorphic understorey on pale sandy to stony loams derived from (Ordovician) meta-sediments or conglomerate.

DistriBution: In an area roughly bounded by Penrose, Goulburn and Braidwood, west of the Sydney Basin sandstones.

CONSERVATION STATUS: not rare.

Notes: In the Penrose-Wingello area this subspecies hybridises with subsp. ledifolia (see under the latter subspecies).

Along the western edge of the Budawang Range subsp. livens is parapatric with subsp. budawangensis. This boundary apparently correlates with a geological boundary, although this needs to be confirmed. $P$. mollis subsp. budawangensis is apparently restricted to (Upper Devonian) Merimbula Formation sandstone, whereas subsp. livens occurs west of this formation. Three specimens housed at NSW, collected along this boundary, are morphologically intermediate between these two subspecies. Although more collections are needed, it seems likely that a narrow hybrid zone exists between the two.

Selected specimens: New Sourh Wales: Central Tablelands: Hume Hwy, Paddys River Bridge, NE end of bridge on bank $50 \mathrm{~m}$ from bridge, $34^{\circ} 39^{\prime} \mathrm{S} 150^{\circ} 08^{\prime} \mathrm{E}$, Davies $424 \mathcal{E}$ Mulcahy, 7 Dec 1987 (NSW ex CBG); Penrose, Blakely, 2 Oct 1938 (NSW 21519); Wingello, Boorman, Feb 1901 (NSW 21520), Aug 1899 (NSW 20944); Barbers Creek, Maiden, Dec 1899 (NSW 21522); Tallong, Forsyth, Jan 1900 (NSW 21523). Southern Tablelands: top of Governors Hill, E side of Goulburn, on Hume Hwy, Rodd 5425, Corbett \& Wilson, 12 Apr 1986 (NSW, K); Goulburn, Moore, Feb 1865 (NSW 21526); Tarago, Froggatt, Oct 1894 (NSW 21527); Church of Mayfield, c. $25 \mathrm{~km} \mathrm{~N}$ of Braidwood, 35'13'S 149 ${ }^{\circ} 8^{\prime}$ E, Kodela, Jan 1989 (NSW 228133); near Warri Bridge, Shoalhaven River, $13 \mathrm{~km}$ NNW of

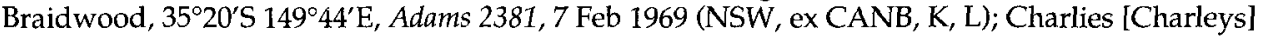
Forest near Braidwood, Boorman, Mar 1909 (NSW 21517); Currockbilly Mt, near Braidwood, Boorman, Sep 1915 (NSW 21516).

$P$. mollis subsp. budawangensis $-P$. mollis subsp. livens intergrades:

Specimens eXamined: New South Wales: Southern Tablelands: $15.6 \mathrm{~km}$ SW of Nerriga on Nerriga-

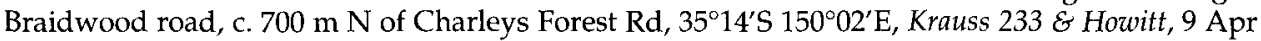
1990 (NSW); c. $1 \mathrm{~km} \mathrm{~S}$ of Nerriga-Braidwood road on Charleys Forest Rd, $35^{\circ} 15^{\prime} \mathrm{S} 150^{\circ} 02^{\prime} \mathrm{E}$, Krauss 232 \& Howitt, 9 Apr 1990 (NSW); foot of Mt Currockbilly, 50 miles [80 km] SW of Nowra, Rodway, 29 Jan 1940 (NSW 38776).

8. Persoonia mollis $R$. Br. subsp. caleyi (R. Br.) S. Krauss $\mathcal{E}$ L. Johnson, comb. et stat. nov.

BAsIONYM: Persoonia caleyi R. Br.

(R. Brown 1830: 13).

LeCTOTYPE (here designated): Jervis Bay, G. Caley, Mar 1801 (BM). This sheet contains four elements. The two on the left (top and bottom) are Caley specimens. The two on the right (middle and far right) were collected by Baxter, the location given being Wilsons Promontory. This location is virtually certain to be incorrect, as the known southern limit of $P$. mollis is Lake Durras. These two elements were probably collected from the Jervis Bay area, as they are morphologically somewhat intermediate between subsp. caleyi and subsp. leptophylla. Of the two Caley elements, the top one is probably subsp. leptophylla. The bottom left element agrees well with the diagnosis and is clearly subsp. caleyi (as here defined), and is therefore here designated the Lectotype. 
Linkia caleyi (R. Br.) Kuntze (Kuntze 1891: 579).

Medium to tall, erect, branching shrub 1.5-4 m high. Young stems silky-pubescent. Leaves \pm soft, linear-lanceolate to narrow-lanceolate, acute, $3-6 \mathrm{~cm}$ long, $0.2-0.6 \mathrm{~cm}$ broad, (sparsely) silky-pubescent on the undersurface when young, the hairs pale, spreading, up to c. $0.7 \mathrm{~mm}$ long, the midvein obscure, the margins recurved to revolute. Buds sparsely silky-pubescent, the hairs $0.1-1 \mathrm{~mm}$ long, spreading. Figure 2.

FLOWERING PERIOD: Late December to July (occasionally later).

HABITAT: Dry and wet sclerophyll forest with a shrubby scleromorphic or mesomorphic understorey, on sandy soil derived from (Permian) Conjola Formation sediments and Wandrawandian Siltstone.

DistRIBUtion: South Coast, south from Currumbene State Forest (Jervis Bay) to Durras Lake (Figure 1).

CONSERVATION STATUS: Not rare.

NOTES: P. mollis subsp. caleyi intergrades with subsp. leptophylla along a hybrid zone roughly from the Huskisson area extending south-west to the Mt Tianjara area. This hybrid zone appears to correlate with the geological division between Nowra Sandstone and Conjola Formation/Wandrawandian Siltstone. However, more collections are needed to clarify the situation. See also under subsp. leptophylla.

It is not known whether subsp. caleyi comes into contact with subsp. budawangensis in the area south of Mt Tianjara, but it may do so. More collections are needed from this area.

The locality of one specimen (Moruya, Baeuerlen, Aug 1890 (NSW)), is most probably incorrect in a strict sense. The known southern limit of this subspecies is Lake Durras (this corresponding to the southern limit of the Conjola Formation sediments). This specimen is subsp. caleyi, but was probably collected north of Lake Durras.

Similarly, a specimen held at MEL (Mt Kaye, East Gippsland, Victoria, Cane, 30 Dec 1977 (MEL 522360, photo)), is almost certainly incorrect in its collecting locality. This specimen is subsp. caleyi, and was probably collected north of Lake Durras. P. mollis has not been otherwise recorded from the area of the supposed Gippsland locality, despite searches subsequent to this collection.

Selected specimens: New South Wales: South Coast: Currarong Rd, c. $2 \mathrm{~km}$ E of Princes Hwy, c. $8 \mathrm{~km}$ SSE of Nowra, 34⒌ $58^{\prime} \mathrm{S} 150^{\circ} 37^{\prime} \mathrm{E}$, Krauss 238, 7 May 1990 (NSW); Currarong Rd, $1.2 \mathrm{~km} \mathrm{~W}$ of Coonemia Rd turnoff, c. $15 \mathrm{~km}$ (direct) SE of Nowra, 34 $59^{\circ} \mathrm{S} 150^{\circ} 44^{\prime} \mathrm{E}$, Krauss 245,8 May 1990 (NSW); 3 miles [4.8 km] SW of Jervis Bay by road on the Cave Beach Rd, $35^{\circ} 09^{\prime} \mathrm{S} 150^{\circ} 41^{\prime} \mathrm{E}$, Coveny 3694, 12 Oct 1971 (NSW); Jervis Bay, Maiden, Jul 1899 (NSW 20945); $1.2 \mathrm{~km}$ along walking track from Steamers Beach, Richards 114, Makinson, Porteners, Mackay \& Gross, 18 Jun 1989 (NSW); Sussex Inlet Heads, Maiden, Feb 1917 (NSW 21506); $10 \mathrm{~km}$ NW of Milton, 35 $16^{\circ}$ 'S $150^{\circ} 21^{\prime} \mathrm{E}$, Adams \& Paijmans 3729, 25 Mar 1981 (NSW, ex CANB); Pigeon House Mtn, $19 \mathrm{~km} \mathrm{~W}$ of Ulladulla, Willis, 2 May 1982 (NSW, ex MEL 610807); Tibbourie, Milton [=Tabourie], Cambage 3512 , 28 Dec 1911 (NSW); SW outskirts of Ulladulla, at end of Deering St, $35^{\circ} 23^{\prime} \mathrm{S} 150^{\circ} 28^{\prime} \mathrm{E}$, Haegi 1768, 10 Feb 1979 (NSW, K, PERTH); between Pretty Beach and Merry Beach (along power line track), Wrigley, 15 Apr 1968 (NSW, ex CBG 024201); $50 \mathrm{~m}$ from Princes Hwy along Bucks Rd, c. 7 km S of Termeil, Krauss 227 \& Howitt, 8 Apr 1990 (NSW); c. 3 km W of Pebbly Beach on track to Princes Hwy, Wheeler 43, 18 May 1975 (NSW, ex CBG 059054, L); Cockwhy Creek, South Brooman State Forest, 27.4 km N of Batemans Bay, Coveny 2920, 29 Jul 1970 (NSW).

\section{Persoonia mollis $R$. Br. subsp. budawangensis $S$. Krauss \& L. Johnson, subsp. nov.}

Subspecie ledifoliae similis sed tepalis brevioribus 7.5-10.5 mm longis (contra 9-11.5 $\mathrm{mm}$ ) atque pilis alabastrorum et paginarum inferiorum foliorum novellorum brevior- 
ibus (longissimis $0.2-0.6 \mathrm{~mm}$ longis, contra $0.4-1 \mathrm{~mm}$ ) distinguitur. Distributio disjuncta est.

Holotype: New South Wales: Southern Tablelands: c. 4 miles [7 km] SW of Corang Peak, Budawang Range, T.G. Hartley 14236, 2 Feb 1974 (NSW).

IsOTYPE: CANB (not seen).

Small to medium, erect, branching shrub 1-2.5 m high. Young stems silky-pubescent with short, pale, spreading hairs. Leaves pliable but not soft, linear-oblong to oblonglanceolate, subacute to acuminate to obtuse, $2-4 \mathrm{~cm}$ long, $0.3-0.6 \mathrm{~mm}$ wide, silkypubescent on the undersurface when young, the hairs c. $0.4 \mathrm{~mm}$ long, pale, the midvein obscure, the margins recurved to revolute. Buds (sparsely) silky-pubescent, the hairs $0.2-0.6 \mathrm{~mm}$ long, pale. Figure 2 .

DeRIVATION OF EPITHET: Refers to the distribution of this subspecies, which is endemic in the Budawang Range.

FLOWERING PERIOD: Late December to early May.

HABITAT: Wet sclerophyll forest, open sclerophyll eucalypt forest, or eucalypt woodland, in exposed and sheltered sites on sandy soils derived from (Upper Devonian) Merimbula Formation sandstone, from 500 to $1100 \mathrm{~m}$ altitude.

Distribution: Endemic to the Budawang Range.

CONSERVATION STATUS: Not rare.

Notes: Although this subspecies strongly resembles subsp. ledifolia, it is quite separate geographically (separated by a distance of at least $60 \mathrm{~km}$, with subsp. leptophylla occurring in the intervening area), and it is possible to distinguish it morphologically from the latter (see key).

For discussion of intermediates see under $P$. mollis subsp. leptophylla, P. mollis subsp. livens, and $P$. mollis subsp. caleyi.

Selected SPECIMENS: New South Wales: Southern Tablelands: Near Camp Rock, Endrick SF, SW of Sassafras, Blaxell 87, 7 Dec 1968 (NSW); Sally Creek, near Budawang Range, Olsen 823, 5 May 1968 (NSW); Valley of the Monoliths, $2 \mathrm{~km} \mathrm{~N}$ of summit of The Castle, c. $28 \mathrm{~km}$ WSW of Milton, $35^{\circ} 15^{\prime} \mathrm{S} 150^{\circ} 11^{\prime} \mathrm{E}$, Briggs 3542, 23 Apr 1972 (NSW); c. $2 \mathrm{~km} \mathrm{~W}$ of Mt Corang along track to Wog Wog' station, northern Budawang Range, c. $32 \mathrm{~km}$ NE of Braidwood, $35^{\circ} 17^{\prime} \mathrm{S} 150^{\circ} 05^{\prime} \mathrm{E}$, Pullen 4986 \& Storey, 26 Sep 1973 (NSW); Bibbenluke Walls, northern Budawang Range, Olsen 990, 16 Feb 1969 (NSW 87957); Currockbilly Mtn, 14 miles [24 km] ENE of Braidwood, Constable 6983, 15 May 1966 (NSW); Currockbilly Mtn near Braidwood, Boorman, Mar 1909 (NSW 22012); summit area of Mt Budawang, c. 10 miles [16 km] ESE of Braidwood, Craven 685, 6 Dec 1965 (NSW, ex CANB, B, BH, CHR, G, K, L, MEL, US); on the road to Mt Budawang, $0.3 \mathrm{~km}$ from NPWS sign (in property), Weston 91, 6 Dec 1979 (NSW, ex SYD); Monga or Sugarloaf Mtn, near Braidwood, Boorman, Mar 1909 (NSW 22010); Kings Hwy, 11 miles [19 km] SE of Braidwood, Adams 1923, 30 Jun 1967 (NSW, ex CANB, K); Clyde Mtn, 10 miles [17 km] ESE of Braidwood, Constable 6934, 13 May 1966 (NSW); Braidwood to Batemans Bay, Salasoo 3761, 25 May 1970 (NSW).

\section{Acknowledgments}

We wish to thank Dr Peter Weston for his support and advice, and David Mackay for the illustrations. Dr Terry Macfarlane, as Australian Botanical Liaison Officer, provided with great speed photos of type material held at $\mathrm{K}$ and $\mathrm{BM}$. We are grateful to the Directors of the following herbaria for loans of specimens: B, BM, K, and NY. One of us (SK) is supported by an Australian Postgraduate Research Award. 


\section{References}

Bentham, G. (1870) Flora Australiensis vol. 5.

Briggs, J.D. \& Leigh, J.H. (1988) Rare or threatened Australian plants 1988, revised edition. Australian National Parks and Wildlife Service Special Publication 14.

Brown, R. (1810a) On the natural order of plants called Proteaceae. Trans. Linn. Soc. 10: 15-226.

Brown, R. (1810b) Prodromus florae Novae Hollandiae et Insulae van-Diemen vol. 1.

Brown, R. (1830) Supplementum primum prodromi florae Novae Hollandiae: exhibens Proteaceas novas.

Jacobs, S.W.L. \& Pickard, J. (1981) Plants of New South Wales (Government Printer: Sydney).

Johnson, L.A.S. \& Briggs, Barbara G. (1975) On the Proteaceae - the evolution and classification of a southern family. Bot. J. Linn. Soc. 70: 83-182.

Kuntze, C.E.O. (1891) Revisio generum plantarum vol. 2.

Meisner, C.F. (1856) Proteaceae. In A. de Candolle, Prodromus systematis naturalis regni vegetabilis vol. 14, part 1.

Schultes, J.A. \& Schultes, J.H. (1827) Mantissa in volumen tertium systematis vegetabilium vol. 3.

Weston, Peter H. \& Johnson, L.A.S. (1991) Taxonomic changes in Persoonia (Proteaceae) in New South Wales. Telopea 4(2): 249-306.

Manuscript received 18 June 1990

Manuscript accepted 2 November 1990 